\title{
Cash Management in Russian Metallurgical and Oil and Gas Companies
}

\author{
Olga Likhacheva $\square$ \\ Candidate of Economic Sciences, Associate Professor, \\ Department of Corporate Finance and Corporate Governance, \\ Financial University under the Government of the Russian Federation, Moscow, Russia, \\ OLihacheva@fa.ru, ORCID
}

\section{Kristina Panasenko}

Adviser to the Department of Analysis and Code of Expenditures of the Department of Interaction with Prefectures of Administrative Districts, Analysis and Code of Expenditures of the Urban Economy Complex of the Department of Finance of the City of Moscow, the Government of Moscow, Moscow, Russia, panasenkoko@mos.ru, $\underline{\text { ORCID }}$

\section{Abstract}

The problem of money management has remained relevant over the past years. The aim of the study is to assess the impact of debt and cash flow on the amount of cash on companies with and without financial constraints. The main hypothesis of the study is that the impact of debt and cash flow on the level of cash depends on financial constraints which were taken as two proxy variables - dividend payment and bond rating. To substantiate the hypothesis put forward, a regression model of the influence of debt and cash flow on the level of cash is built in the work.

For the analysis, large Russian companies in the metallurgical and oil and gas industries were sorted in accordance with financial constraints. Based on the results of the constructed regression model, the following conclusions can be drawn. Borrowed funds of companies negatively affect the amount of cash on the balance sheet, regardless of the presence and type of financial constraints. Cash flow is not statistically significant for companies without financial constraints.

This study has some limitations. The research results can be useful for corporate CFOs in order to optimize cash balances.

Keywords: cash, cash-management, cash flow, debt, financing, financial constraints

For citation: Likhacheva, O. and Panasenko, K. (2021) "Cash Management in Russian Metallurgical and Oil and Gas Companies”, Journal of Corporate Finance Research | ISSN: 2073-0438, 15(3), pp. 60-69. doi: 10.17323/j.jcfr.20730438.15.3.2021.60-69. 


\section{Introduction}

All over the world companies focus increasingly on cash management. It is especially relevant for companies with financial constraints (insofar as such companies cannot get cash through debt financing) because their policy for balance maintenance may be changed significantly.

This paper studies financial constraints in cash management of Russian metallurgical and oil and gas companies. Companies from these industry sectors are leaders in bond issuing in the Russian market. They have a high debt level, therefore, probably financial constraints will have a stronger influence on them. The research purpose is to evaluate influence of debt and cash flow on the amount of balance.

The present paper is of practical importance for the companies concerned with enhancement of efficiency of their cash management. Conclusions and recommendations offered in the paper may be applied in construction of corporate cash flow management systems in order to optimize cash balance. Comprehensive analysis performed in the paper using a sample of Russian metallurgical and oil and gas companies allows us to make conclusions on the extent of influence of debt and cash flow on the amount of cash in the companies with financial constraints and without them. The paper considers two types of financial constraints: dividend payment and bond rating.

At the beginning of the paper, we review the studies dedicated to the range of problems related to dependence of corporate balance on the debt level and amount of cash flows (the trade-off theory and pecking order theory, study of financial constraints), put forward hypotheses on influence of debt and cash flow on the cash amount in companies with financial constraints and without them. Then, on the basis of the sample of Russian metallurgical and oil and gas companies we assess influence of debt and cash flow on the amount of balance.

\section{Cash Management: Review of Studies}

Maintaining of the necessary cash balance (cash equivalents are considered in the present paper as cash) and investing of surplus cash are the main objectives of cash management. The amount of cash depends on the following factors: company characteristics, banks' attitude, availability of capital markets and other factors of financial management. However, a complex character of the factors and difficulty in cash management limit capability of many companies for efficient cash management. Instead, as a rule companies define a target cash balance [1].

The trade-off theory and pecking order theory explain the amount of cash balance. So, according to the trade-off theory companies adjust their cash up to the optimum amount at which the marginal revenue from possession of cash equals marginal costs. In line with the theory by Keynes [2] the amount of corporate cash depends on the amount of transaction costs, precautionary and speculative motives.
In spite of advantages of cash "surplus" it has a range of drawbacks. The rate of return of cash or liquid securities is low due to a liquidity premium. The cash allocated among shareholders is double taxed: at the corporate and individual level [3]. As per Jensen [4] cash may also increase agency costs. Companies with larger cash amounts do not need access to the capital market for financing, so their managers are out of the market control. If there is no such control managers may pursue their own ends instead of those of shareholders, as a result, corporate performance will be reduced.

Early studies of cash balance by Baumol [5], Tobin [6], Miller and Orr [7] were focused on calculation of its optimum amount, later studies - on empiric rather than theoretical problems. Thus, John [8] studies the relation between financial constraints and cash of corporations. The author provides proof that the cost of financial constraints is related positively to the intent to own cash using various proxies for the basic variable. Beltz and Murray [9] study the trade-off theory in relation to cash and their results confirm the forecasts according to the trade-off theory. Kim et al. [3] and Opler et al. [10] conducted two fundamental studies of the factors which prompted companies to own cash. Kim et al. [3] study the optimum amount of investment into corporate cash according to the trade-off theory. They consider that cash holdings are an increasing function of the external financing cost, cash flow dispersion and future investment opportunities. And vice versa, cash decreases along with increase of opportunity costs. Opler et al. [10] examine two different points of view on possession of cash: the trade-off theory and pecking order theory. They provide empiric proof that both views explain the policy of cash ownership. They think that the amount of cash is an increasing function of growth opportunities, cash flow dispersion and non-cash working capital and a decreasing function of the company size and bond rating (Park [11]).

Unlike the trade-off theory of cash balance maintenance the pecking order theory contemplates that there is no optimum balance. According to Myers and Majluf [12] information asymmetry between corporate managers and external investors increases the external financing cost. Relatively less informed investors are reluctant to pay the full cost of securities issued by the company and try to decrease it. Therefore, companies have to sell their securities at a discount, thus, incrementing the external financing. In case of external financing debt is of higher priority than equity capital due to a higher cost of equity capital. The pecking order of financing is as follows: first, companies use internal sources, then - debt, shares are the last financing source in the pecking order. According to this theory the debt level is defined by decisions related to financing and investment implying that there is no optimum capital structure. As with financial leverage cash balance is a result of corporate decisions related to investment and financing. Companies apply their cash flows to finance their investment opportunities or projects, pay off debts in due time and then accumulate unused cash 
flows as cash balance, when possible. If cash flow does not cover the abovementioned expenses companies apply accumulated cash in order to avoid external financing. If cash flow from operations and cash are insufficient to cover all expenses additional financing is necessary. Cash inflows and outflows define the amount of accumulated cash. It is indicative of absence of the optimum cash balance.

Although the pecking order theory explains corporate cash balance no empiric studies had been carried out before Opler et al. [10]. They verified correspondence of the trade-off theory as well as the pecking order theory on the basis of behavior of target cash balance applying the model of Shyam-Sunder and Myers [13]. The results confirm that both theories explain change of cash balance to a considerable degree. The distinction between the trade-off theory and the pecking order theory concerning the policy of cash balance is not clear. Opler et al. [10] presume that this distinction becomes indefinite because the cost of external financing acquires more importance in the pecking order theory (Musnadi et al. [14]).

Study of influence of financial constraints on cash balance is of relevance. Against the background of the perfect capital market a company has an instant access to the external capital market when there is a positive net present value (NPV). External means may be replaced with internal financing sources. In light of this, cash balance is of no significance because it entails a range of expenses (Kim et al. [3]; Opler et al. [10]). However, in the actual world the capital market is imperfect which means that companies may have different opportunities of accessing the capital market. Difference in accessibility may be due to the fact that each company has a different cost of external financing represented by transaction costs. A company with high transaction costs has a limited access to the capital market and pursues the financial policy aimed at saving cash balance. Motivation to hold savings grows when companies have a volatile cash flow and ample investment opportunities. On the other hand, companies without financial constraints do not gain much from maintaining cash balance because they can have access and raise funds in the capital market when necessary. Bates et al. [15] and Hall have proven empirically that companies with financial constraints have more cash than those without such constraints.

Several studies consider influence of financial constraints. Almeida et al. [16] examine the interrelation between financial constraints and availability of cash with a particular focus on structural changes of cash flow depending on the amount of cash. The amount of cash balance increases along with growth of cash flow in companies with financial constraints. Cash of companies without financial constraints influences their cash flows. Acharya et al. [17] study the interrelation between debt and money holdings applying the financial constraints concept. They assume that monetary and debt policies are developed simultaneously supposing that they are related to each other. They create the model which takes into consideration this endogenous relationship and find out that companies with financial constraints show a positive relation between debt and cash holdings while companies without financial constraints show a negative relation. Companies with financial constraints save more funds in case of increase of leverage. Companies without financial constraints reduce the debt level for the purpose of maintaining cash balance.

We will use a modified version of Almeida et al. [16] for empiric analysis. We will divide companies into two groups according to financial constraints they face (Table 1). Companies with financial constraints are less likely to pay dividends (Fazzari et al. [18]; Sarkar, Zhang [19]). Almeida et al. [16] use top (or the lowest) 30 deciles of dividend payments as the critical value of financially unconstrained (financially constrained) companies. If a company pays dividends it is considered to have no financial constraints. Otherwise, it is presumed that the company is financially constrained. The bond rating is descriptive of the company's creditworthiness evaluated by the capital market. A company without a public bond rating within the studied period is considered to be the one with financial constraints. If bonds of a company have a rating within such period the company has no financial constraints (Table 1).

Table 1. Measuring financial constraints

\begin{tabular}{|c|c|c|}
\hline Item & $\begin{array}{l}\text { Financial } \\
\text { constraint }\end{array}$ & Notes \\
\hline \multirow[t]{2}{*}{$\begin{array}{l}\text { Dividend } \\
\text { payment }\end{array}$} & $\begin{array}{l}\text { Financially } \\
\text { constrained }\end{array}$ & $\begin{array}{l}\text { Dividends not } \\
\text { paid }\end{array}$ \\
\hline & $\begin{array}{l}\text { Financially } \\
\text { unconstrained }\end{array}$ & Dividends paid \\
\hline \multirow[t]{2}{*}{ Bond rating } & $\begin{array}{l}\text { Financially } \\
\text { constrained }\end{array}$ & No bond rating \\
\hline & $\begin{array}{l}\text { Financially } \\
\text { unconstrained }\end{array}$ & Bond rating \\
\hline
\end{tabular}

Source: compiled by the author.

\section{Computational and Analytical Base Verified Hypotheses}

In order to conduct regression analysis of influence of debt and cash flow on cash balance it is necessary to introduce hypotheses which confirm or disprove of such influence. First, we shall consider the interrelation between cash and debt.

As far as is known, cash is related negatively to debt. Maintenance of cash balance and debt settlement are equivalent from the point of view of provision of cash holdings (Opler et al. [10]). Cash may be used to finance new investments and it replaces a part of debt (cash - negative debt). Besides, John [8] uses the leverage ratio as a proxy in case of issue of a new debt. He supposes that companies with a high leverage may get access to the capital market and raise funds; consequently, they are unmotivated to hold cash. This enhances the negative interrelation between debt and 
cash. In accordance with the trade-off theory the interrelation between debt and cash is negative. Along with growth of the financial indebtedness ratio the probability of bankruptcy increases while the cost of financial problems also increments (D’Mello et al. [20]).

According to the pecking order theory there is also a negative interrelation between debt and cash. When the financing requirement is high and even exceeds cash flow companies use undistributed profit, funds. If undistributed profit is not sufficient to cover the financing requirement companies raise additional debt funding. As long as the amount of cash decreases the debt may increment. However, when cash flow is sufficient to cover the investment needs, first, companies pay off debts and accumulate cash. As a rule, debt is related to cash flow negatively.

Now we are going to consider financial constraints. Acharya et al. [17] think that financial constraints have an impact on the interrelation between debt and cash. A company with a limited access to the capital market prefers to accumulate cash instead of repaying debts. However, companies without financial constraints pay off debts before accumulating cash. The interrelation between debt and cash holdings varies depending on financial constraints.

According to Acharya et al. [17] the value of the leverage ratio influences cash balance. For metallurgical and oil and gas companies with a limited access to the capital market debt is related directly to cash holdings. A high debt ratio of such companies may enhance motivation to maintain cash balance or to prepare for a possible default or to avoid financial difficulties. Cash may replace debt for oil and gas and metallurgical companies without financial difficulties. Along with increase of the debt level such companies are motivated to reduce debt instead of maintaining cash balance.

The present research assumes that the relation between debt and cash depends on financial constraints.

Hypothesis 1: the relation between debt and cash differs depending on financial constraints.

Hypothesis 1a: debt is related positively to cash for companies with financial constraints.

Hypothesis $\mathbf{1 b}$ : debt is related negatively to cash for companies without financial constraints.

Now, let us examine the interrelation between cash and cash flow. Cash flow is considered to be a source of investment financing. Cash flow may replace cash in financing and, thus, it will be related negatively to cash balance. However, a reverse situation is possible. According to the pecking order theory companies with a larger cash flow may have more funds as a result of operating activity. If cash flow from operations exceeds investment needs companies pay off debt and then accumulate cash. As a rule, cash balance increments along with cash flow.

Similarly to the interrelation of debt and cash the relation between cash flow and cash balance may become more transparent if the financial constraints concept is applied. Almeida et al. [16] emphasize this role of financial con- straints in the interrelation between cash flow and cash balance. They presume that a company facing difficulties with access to the capital market is motivated to hold cash balance from its cash flow. The accumulated funds assist the company in avoiding high expenses related to external financing. However, this relation is insignificant for companies without financial constraints. A similar grounding may be applied to oil and gas and metallurgical companies. The companies which are unable to get financing in the capital market usually maintain cash balance and use it to finance investments and other expenses. But for companies without financial constraints the relation is negative because cash and cash flows may be interchangeable for the purpose of financing. There is a negative interrelation between cash flow and cash balance.

Thus, the present research puts forward the hypothesis that this relation depends on the extent of financial constraints.

Hypothesis 2: the relation between cash flow and cash balance changes depending on financial constraints.

Hypothesis 2a: cash flow is related positively to cash balance for companies with financial constraints.

Hypothesis 2B: cash flow is related negatively to cash balance for companies without financial constraints.

\section{Methodology}

The advanced hypotheses allowed to develop the model of influence of debt and cash flow on cash balance.

According to the pecking order theory if cash flow from operations and cash holdings cannot cover cash outflows represented by investments and debt repayment the company issues additional debt. It is suggested that the existing amount of internal cash flows has a negative impact on borrowed funds which is indicative of an internal interrelation between debt and cash. Foreign studies confirm this endogenous relationship. Opler et al. [10] assert that corporate monetary policy is determined on the basis of lending policy. This endogenous relationship is left out of their model. D'Mello et al. [20] study the endogenous relationship between debt and cash holdings. Thus, this research will comprise the endogenous relationship between debt and cash. The analyzed data from Korea also showed a negative correlation between variables with consideration to data endogeneity (Park [11]).

The ordinary least squares method of linear regression (OLS) does not apply because it gives biased estimators, i.e. there may be an error in the results. Instead, we use in this paper a two-stage least-squares regression model (2SLS) which provides avoidance of endogeneity by means of sequential application of parameters.

The first stage of the 2SLS model is the search for permissible instrumental variables which will not correlate to the variables of the regression. For this purpose two assumptions for the permissible instrumental variables should be fulfilled. Second, they are not associated with an unbiassed error. Analysis of literature sources yielded a set of instrumental variables for debt and company size. Some research- 
ers assert that many companies finance their growth opportunities using debt (Upneja, Dalbor [21]; Tang, Jang [22]). As the company size grows it may have a higher debt level.

Thus, the obtained regression model of analysis of influence of debt and cash flow on cash balance is as follows:

$$
\begin{aligned}
& \mathrm{CASH}_{i, t}=\beta_{0}+\beta_{1} \mathrm{DEBT}_{i, t}+\beta_{2} \mathrm{CASHFLOW}_{i, t}+ \\
& +\beta_{3} \mathrm{PPE}_{i, t}+\beta_{4} \mathrm{NWC}_{i, t}+\beta_{5} \mathrm{STD}_{i, t}+\beta_{6} \mathrm{CE}_{i, t}+ \\
& +\beta_{7} \mathrm{Age}_{i, t}++\beta_{8} \operatorname{LnSIZE}_{i, t}+\varepsilon_{i, t}
\end{aligned}
$$

where $\mathrm{CASH}_{i, t}$ is cash and cash equivalents of $i$ company divided by assets in the $t$ year; $D E B T i_{i, t}$ is debt of $i$ company divided by assets in the $t$ year; CASHFLOW $W_{i, t}$ is cash flow of $i$ company (earnings after interest and taxes before amortization of property, plant and equipment and intangible assets) divided by assets in the $t$ year; $P P E_{i, t}$ is property, plant and equipment of $i$ company divided by assets in the $t$ year; $N W C_{i, t}$ is net working capital (i.e. Current Assets - Current Liabilities - Cash) of $i$ company for the previous 12 quarters; $C E_{i, t}$ is capital expenditures of $i$ company divided by assets in the $t$ year; $A g e_{i, t}$ is age of $i$ company (in months); $\operatorname{LnSIZE}_{i, t}$ is the size of $i$ company in the $t$ year (total assets logarithm); $\varepsilon_{i, t}$ - error.

Cash balance $(C A S H)$ is a dependent variable; the leverage ratio $(D E B T)$ and cash flow (CASHFLOW) are two independent variables. The rest five variables in this model are control variables.

In order to test reliability we present the results of the OLS regression. To compare companies with financial constraints to companies without financial constraints we calculated a regression of four pairs of subgroups in this paper (two regression models $\times$ two measurements of financial constraints).

It is necessary to check the problem of endogeneity and instrument reliability before using proxy variables. The Sargan test is applied to verify instrument reliability. The null hypothesis for the Sargan test states that the instrument variable does not correlate with an error. The null hypothesis for verification of variables is not rejected, therefore, we may consider that instrumental variables are correct.
In order to verify existence of the endogeneity problem in the model with a new instrumental variable it is necessary to conduct the Durbin-Wu-Hausman test (DWH). The DWH test compares consistent estimators of OLS to 2SLS estimators. If the null hypothesis is rejected it means that the results of our regression will have inconsistent estimators. However, according to our data the hypothesis cannot be rejected, therefore in this research we will use instrumental variables.

\section{Data Description}

At the next stage, after developing the model we created a sample of Russian metallurgical and oil and gas companies which we used to evaluate influence of debt and cash flow on cash balance. Companies from these industry sectors are leaders of the Russian market in issue of bonds. They have a high debt level and therefore, probably, financial constraints will exert a greater impact. We chose for the research the period from 2008 to 2018 - 11 years (2019 and 2020 of pandemic have not been added to the calculation because of a greater volatility of values).

The data used in the present research has been obtained from Bureau van Dijk, RUSLANA. After uploading the information was processed and verified for outlying data and financial information for the whole chosen period. So, after data processing we chose 197 metallurgical companies and 135 oil and gas companies.

\section{Empiric Part: Regression Analysis}

We start analysis of the results with the aggregated sample of Russian metallurgical and oil and gas companies irrespective of financial constraints. There is codirectional dynamics of cash balance and cash flow in the period from the first quarter of 2008 to the fourth quarter of 2018. The larger free cash flows of companies the more funds they hold for potential internal financing. These results are compliant with the pecking order theory.

See the descriptive information of the sample for the metallurgical industry in Table 2, for the oil and gas industry -

\begin{tabular}{|c|c|c|c|c|}
\hline Indicator & Mean & Standard deviation & Minimum & Maximum \\
\hline Cash balance $(\mathrm{CASH})$ & 0.122 & 0.118 & 0.000 & 0.400 \\
\hline $\operatorname{Debt}(D E B T)$ & 0.978 & 0.520 & 0.248 & 1.804 \\
\hline Cash flow (CASHFLOW) & 0.075 & 0.089 & -0.026 & 0.274 \\
\hline Property, plant and equipment $(P P E)$ & 0.781 & 0.157 & 0.457 & 0.998 \\
\hline Net working capital $(N W C)$ & 0.098 & 0.060 & 0.002 & 0.209 \\
\hline Standard deviation of cash flow (STD) & 0.845 & 0.169 & 0.704 & 1.043 \\
\hline Capital expenditures (Capex) & 0.530 & 0.365 & -0.077 & 0.964 \\
\hline Company age $(\mathrm{Age})$ & 17.609 & 22.892 & 5.000 & 264.000 \\
\hline Company size $(L n S I Z E)$ & 14.047 & 0.481 & 13.157 & 14.589 \\
\hline
\end{tabular}
in Table 3.

Table 2. Descriptive statistics of metallurgical industry variables

Source: authors' calculation applying RUSLANA. 
In the metallurgical industry (Table 2) the mean ratio of cash to total assets amounts to $12.2 \%$. Debt exceeds $97.8 \%$. It means that metallurgical companies depend strongly on debt financing. Property, plant and equipment account for a high percentage of assets (over 70\%). Cash flow in the total assets amounts to approximately $7.5 \%$. Cash flow volatility calculated as a ratio of standard deviation of cash flows to their mean value for three years amounts to $84.5 \%$. Such volatility is indicative of serious fluctuations of cash flows.

Table 3. Descriptive statistics of variables in oil and gas companies

\begin{tabular}{|c|c|c|c|c|}
\hline Indicator & Mean & Standard deviation & Minimum & Maximum \\
\hline Cash balance $(\mathrm{CASH})$ & 0.074 & 0.188 & 0.000 & 0.729 \\
\hline Debt $(D E B T)$ & 0.912 & 0.451 & 0.000 & 2.000 \\
\hline Cash flow (CASHFLOW) & 0.062 & 0.131 & -0.133 & 0.238 \\
\hline Property, plant and equipment $(P P E)$ & 0.550 & 0.342 & 0.000 & 0.951 \\
\hline Net working capital (NWC) & 0.383 & 0.196 & 0.119 & 0.855 \\
\hline Standard deviation of cash flow (STD) & 0.380 & 0.149 & 0.223 & 0.522 \\
\hline Capital expenditures (Capex) & 0.626 & 0.358 & -0.594 & 0.511 \\
\hline Company age (Age) & 17.269 & 11.378 & 5.000 & 103.000 \\
\hline Company size (LnSIZE) & 17.498 & 0.448 & 16.999 & 18.500 \\
\hline
\end{tabular}

Source: authors' calculation applying RUSLANA.

Table 4. Comparison of key variables of companies with and without financial constraints

\begin{tabular}{|c|c|c|c|c|}
\hline \multirow{2}{*}{ Indicator } & \multicolumn{2}{|c|}{ Dividends } & \multicolumn{2}{|c|}{ Bonds } \\
\hline & with constraints & without constraints & with constraints & without constraints \\
\hline Cash balance $(C A S H)$ & 0.093 & 0.079 & 0.090 & 0.089 \\
\hline Debt $(D E B T)$ & 0.635 & 0.667 & 0.677 & 0.595 \\
\hline Cash flow (CASHFLOW) & 0.029 & 0.033 & 0.030 & 0.030 \\
\hline Number of observations & 196 & 101 & 165 & 137 \\
\hline
\end{tabular}

Source: authors' calculation applying RUSLANA.

In the oil and gas industry (Table 3 ) the average amount of cash on the books of oil and gas companies is approximately $7 \%$ which is less than in metallurgical companies. Debt of oil and gas companies is a little less but it is still rather high $-91.2 \%$, which is indicative of a large amount of borrowed funds.

Now, we are going to verify data for the multicollinearity problem because if it exists our estimators will be inefficient. We built Pearson correlation matrices of variables for metallurgical and oil and gas companies. So, we may make the conclusion that debt to equity ratio, property, plant and equipment; capital expenditures, the company age and company size correlate negatively to cash holdings. Cash flow, net working capital and cash flow volatility correlate positively to cash holdings. However, correlation in both industries is not strong, therefore there are no assumptions that the data is multicollinear.
Further we are going to compare variables in the groups with financial constraints and without them (Table 4).

As a rule, companies with financial constraints have more cash than companies without constraints. Further statistical testing is necessary to verify this hypothesis in terms of money. It remains to be seen whether companies with financial constraints have a greater debt than companies without financial constraints. First, we consider dividend payment as a financial constraint. The companies without financial constraints (do not pay dividends) show a bigger debt to equity ratio as compared to the companies with financial constraints. In the periods of reducing the debt load of Russian metallurgical and oil and gas companies cash outflows used to repay previous loans and credits decrease while high indicators of operations' profitability allow companies to increase the dividends they pay. There is also a trend in many studied companies to improve their 
investment attractiveness by increasing shareholders' dividends even despite reducing of net cash flow (in 20112013 and 2017-2018).

Now we pass on to another proxy variable - bond rating. Companies with bond rating as well as companies without bond rating prefer to maintain the same amount of cash at the end of the year which indicates that this financial constraint has no influence on the value of cash savings.
Table 5 is illustrative of comparison of cash between companies with financial constraints and without them. The table shows no statistically significant difference between groups of companies with financial constraints and without them.

The models of the OLS and 2SLS regressions were used for analysis of the collected data. See the results of the OLS and 2 SLS regressions for companies with financial constraints in Table 6.

Table 5. Comparison of cash to total assets between groups of companies with and without financial constraints

\begin{tabular}{lll} 
Indicator & Dividends & Bonds \\
Companies with financial constraints & $\begin{array}{l}0.093 \\
(196)\end{array}$ & $\begin{array}{l}0.089 \\
(165)\end{array}$ \\
\hline Company without financial constraints & 0.079 & 0.090 \\
Difference in cash & $(101)$ & $(137)$
\end{tabular}

Note: $* \mathrm{p}<0.1 ; * * \mathrm{p}<0.05 ; * * * \mathrm{p}<0.01$; the number of observations is enclosed in parentheses.

Source: authors' calculation applying RUSLANA.

Table 6. Impact of debt on the amount of cash in a company with financial constraints (OLS and 2SLS)

\begin{tabular}{|c|c|c|c|c|c|c|c|c|}
\hline \multirow{3}{*}{ Indicator } & \multicolumn{4}{|c|}{ Dividend payment (no payment) } & \multicolumn{4}{|c|}{ Bond rating (no bond rating) } \\
\hline & \multicolumn{2}{|c|}{ OLS } & \multicolumn{2}{|c|}{ 2SLS } & \multicolumn{2}{|c|}{ OLS } & \multicolumn{2}{|c|}{ 2SLS } \\
\hline & Ratio & $\mathbf{T}$ & Ratio & $\mathbf{T}$ & Ratio & $\mathbf{T}$ & Ratio & $\mathbf{T}$ \\
\hline Debt $(D E B T)$ & -0.268 & $-1.962^{\star * *}$ & -0.822 & $-6.69^{* * *}$ & -0.239 & $-8.56^{\star * *}$ & -0.781 & $-8.01^{\star * *}$ \\
\hline $\begin{array}{l}\text { Cash flow } \\
(C A S H F L O W)\end{array}$ & 0.311 & $3.08^{\star * *}$ & 0.199 & $2.49^{* * *}$ & 0.333 & $3.63^{\star * *}$ & 0.164 & $2.18^{\star * *}$ \\
\hline $\begin{array}{l}\text { Property, plant and } \\
\text { equipment }(P P E)\end{array}$ & -0.250 & $-9.92^{\star \star \star}$ & -0.113 & $-2.87^{\star \star \star}$ & -0.227 & $-8.81^{\star * \star}$ & -0.075 & $-2.04^{\star * *}$ \\
\hline $\begin{array}{l}\text { Net working capital } \\
(N W C)\end{array}$ & -0.105 & $-4.55^{\star \star \star}$ & -0.296 & $-5.34^{\star \star \star}$ & -0.097 & $-4.69^{\star \star \star}$ & -0.238 & $-5.92^{* * *}$ \\
\hline $\begin{array}{l}\text { Standard deviation of } \\
\text { cash flow (STD) }\end{array}$ & 0.722 & $5.20^{\star * *}$ & 0.758 & $5.86^{* * *}$ & 0.893 & $10.20^{* * *}$ & 0.763 & $8.32^{\star \star \star}$ \\
\hline $\begin{array}{l}\text { Capital expenditures } \\
(C E)\end{array}$ & -0.067 & -1.37 & -0.482 & $-3.86^{\star * \star}$ & -0.121 & $-2.27^{\star * *}$ & -0.472 & $-4.22^{\star * *}$ \\
\hline Company age $(A g e)$ & 0.000 & $4.23^{\star * *}$ & 0.000 & $3.58^{\star * *}$ & 0.000 & $6.21^{\star * *}$ & 0.000 & $5.87^{\star * *}$ \\
\hline Constant (CONSTANT) & 0.364 & $11.82^{\star * *}$ & 0.607 & $10.39^{* * *}$ & 0.334 & $9.71^{\star * *}$ & 0.579 & $11.79^{* * *}$ \\
\hline$N$ & \multicolumn{2}{|c|}{196} & \multicolumn{2}{|c|}{196} & \multicolumn{2}{|c|}{165} & \multicolumn{2}{|c|}{165} \\
\hline$F$ & \multicolumn{2}{|c|}{19.90} & \multicolumn{2}{|c|}{28.87} & \multicolumn{2}{|c|}{102.91} & \multicolumn{2}{|c|}{49.50} \\
\hline$R^{2}$ & \multicolumn{2}{|c|}{0.505} & \multicolumn{2}{|c|}{0.178} & \multicolumn{2}{|c|}{0.570} & \multicolumn{2}{|c|}{0.144} \\
\hline
\end{tabular}

Source: authors' calculation applying RUSLANA. 
From the first line of Table 6 we see that debt is negatively related to cash. Irrespective of the chosen model (OLS and 2 SLS) the variable is significant at a $1 \%$ level. It means that the less debt is raised by a company the larger is the amount of its cash (irrespective of the way of measuring of financial constraints: the fact of dividend payment or existing bond rating). So, if debt is decreased by $1 \%$ the value of free cash flows will be reduced by $0.8 \%$ more. Therefore hypothesis 1 (influence of debt may be different due to financial constraints) and hypothesis 1a (debt has a positive impact on the cash amount in companies with financial constraints) are rejected. The second line of Table 6 shows that cash flow is related posi- tively to cash holding in the OLS and 2SLS models. The influence is significant and positive, i.e. with a larger cash flow a company may hold bigger amounts at its bank accounts irrespective of the type of its financial constraints. When there is a financial constraint of raising borrowed funds increase of corporate cash flows raises the probability and also strengthens companies' desire to hold a large amount in their accounts. The results are in line with the conclusions made in the paper by Almeida et al. [16]. Hypothesis 2a of a positive influence of cash flows cannot be rejected.

Let us see how debt influences the amount of cash in a company without financial constraints (Table 7).

Table 7. Impact of debt on the amount of cash in a company without financial constraints (results of OLS and 2SLS models)

\begin{tabular}{|c|c|c|c|c|c|c|c|c|}
\hline \multirow{3}{*}{ Indicator } & \multicolumn{4}{|c|}{ Dividend payment (no payment) } & \multicolumn{4}{|c|}{ Bond rating (no bond rating) } \\
\hline & \multicolumn{2}{|c|}{ OLS } & \multicolumn{2}{|c|}{ 2SLS } & \multicolumn{2}{|c|}{ OLS } & \multicolumn{2}{|c|}{ 2SLS } \\
\hline & Ratio & $\mathbf{T}$ & Ratio & $\mathbf{T}$ & Ratio & $\mathbf{T}$ & Ratio & $\mathbf{T}$ \\
\hline Debt (DEBT) & -0.301 & $-6.71^{\star * *}$ & -0.522 & $-6.29^{* * *}$ & -0.430 & $-10.4^{* * *}$ & -0.961 & $11.88^{* * *}$ \\
\hline $\begin{array}{l}\text { Cash flow } \\
(C A S H F L O W)\end{array}$ & 0.086 & 0.62 & -0.127 & -0.87 & -0.461 & -1.53 & 0.297 & 0.78 \\
\hline $\begin{array}{l}\text { Property, plant and } \\
\text { equipment }(P P E)\end{array}$ & -0.125 & $-7.05^{\star * *}$ & -0.083 & -3.75 & -0.174 & $-10.37^{* * *}$ & -0.161 & $-7.68^{\star * *}$ \\
\hline $\begin{array}{l}\text { Net working capital } \\
(N W C)\end{array}$ & -0.148 & $-4.73^{\star * *}$ & -0.208 & $-5.28^{\star * \star}$ & -0.303 & $-3.05^{\star * *}$ & -0.544 & $-6.14^{\star * \star}$ \\
\hline $\begin{array}{l}\text { Standard deviation of } \\
\text { cash flow (STD) }\end{array}$ & 1.077 & $11.97^{\star * *}$ & 0.993 & $14.78^{\star \star \star *}$ & 0.317 & 1.08 & 1.806 & $3.49^{* * *}$ \\
\hline $\begin{array}{l}\text { Capital expenditures } \\
(C E)\end{array}$ & -0.200 & -1.13 & -0.143 & -1.15 & 0.004 & 0.06 & -0.160 & $-1.76^{\star}$ \\
\hline Company age (Age) & 0.000 & $7.55^{\star * *}$ & 0.000 & $6.95^{* * *}$ & 0.000 & $5.72^{\star * *}$ & 0.000 & $5.98^{\star * *}$ \\
\hline Constant (CONSTANT) & 0.283 & $7.20^{* * *}$ & 0.394 & $8.96^{* * *}$ & 0.392 & $11.53^{\star * *}$ & 0.620 & $15.56^{* * *}$ \\
\hline $\mathrm{N}$ & \multicolumn{2}{|c|}{101} & \multicolumn{2}{|c|}{101} & \multicolumn{2}{|c|}{137} & \multicolumn{2}{|c|}{137} \\
\hline $\mathrm{F}$ & \multicolumn{2}{|c|}{55.45} & \multicolumn{2}{|c|}{80.38} & \multicolumn{2}{|c|}{17.40} & \multicolumn{2}{|c|}{22.66} \\
\hline$R^{2}$ & \multicolumn{2}{|c|}{0.682} & \multicolumn{2}{|c|}{0.625} & \multicolumn{2}{|c|}{0.559} & \multicolumn{2}{|c|}{0.059} \\
\hline
\end{tabular}

Source: authors' calculation applying RUSLANA.

Companies without financial constraints show the result similar to the one of companies with financial constraints. The debt level of the company has a negative impact on cash balance. The result is statistically significant and indicates that companies without financial constraints may replace easily the internal financing with the external one. Besides, in case of increase of debt by $1 \%$ in companies with bond rating cash will decrease by $0.96 \%$. It may be due to the fact that the price of raising a bank loan or issue of a bond-secured loan is lower than issue of shares, hence, it is more available for companies. Thus, the conclusion, according to which companies with less financial constraints related to debt use less cash, accords with the conclusions by Acharya et al. [17]). Hypothesis $1 \mathrm{~b}$ (on a negative impact of debt on cash) is not rejected and hypothesis 1 (the relation between debt and cash differs depending on financial constraints) is accepted partially.

As opposed to the forecast of the researchers whose publications have been mentioned in this paper cash flow is statistically insignificant for companies without financial constraints. This result was obtained both for companies not paying dividends and for those which have financial bond 
rating. Companies with a better access to the capital market are not motivated to save funds from cash flow (Almeida et al. [16]). Cash flow cannot replace cash balance for financing of the company. Hypothesis $2 \mathrm{~b}$ is rejected and hypothesis 2 (the interrelation between cash flow and cash balance changes depending on financial constraints) may be rejected only partially.

Control variables show that the greater volatility of cash flow the larger the amount a company holds in its accounts. This result applies to both: companies with financial constraints and companies without them. When the variation of cash grows companies try to hold more cash because due to a serious volatility they need more cash to cover a possible deficiency of cash flows or a provisional demand for liquidity (Kim et al. [3]). Non-cash working capital is related negatively to cash confirming that it may be replaced with cash (Opler et al. [10]).

\section{Conclusion}

The purpose of the research was to evaluate influence of debt and cash flow on the amount of cash in companies. This paper shows the role of financial constraints related to maintenance of cash balance of large metallurgical and oil and gas companies which have not been taken into consideration before. We have analyzed the interrelation between debt, cash flow and cash balance of a company in case of different financial constraints. Academic literature explains dependence of the described variables using existing financial theories, such as the trade-off theory and pecking order theory. However, study of the interrelation between debt and cash flows led to ambiguous conclusions. This paper adds to understanding of the interrelation between variables on the basis of the financial constraints concept. For the conducted analysis the companies were chosen on the basis of financial constraints applying two proxy variables: dividend payment and bond rating. Taking into consideration the endogenous relationship between debt and cash balance the 2SLS regression has been used in the paper.

The paper established that debt had a negative impact on the amount of cash in large Russian metallurgical and oil and gas companies irrespective of existence of financial constraints and their type. However, there is a slight difference in the extent of debt influence.

As a rule, companies with financial constraints with larger cash flows have larger cash balance (difficulties in accessing the capital market makes companies hold the unused cash flow in the form of cash). Companies without financial constraints show no systematic consistent pattern between cash flows and cash balance. The results accord with Almeida et al. [16].

This paper may offer recommendations to metallurgical and oil and gas companies with financial constraints in the sphere of financial policy.

\section{References}

1. Megginson W.L., Smart S.B. Introduction to corporate finance. Mason, $\mathrm{OH}$ : Thomson/SouthWestern; 2006. 965 p.

2. Keynes J.M. The general theory of employment, interest, and money. London: Macmillan; 1936. 403 p.

3. Kim C.S., Mauer D.C., Sherman A.E. The determinants of corporate liquidity: Theory and evidence. Journal of Financial and Quantitative Analysis. 1998;33(3):335-359. https://doi. org/10.2307/2331099

4. Jensen M.C. Agency cost of free cash flow, corporate finance, and takeovers. The American Economic Review. 1986;76(2):323-329.

5. Baumol, William J. The Transactions Demand for Cash: An Inventory Theoretic Approach. Quarterly Journal of Economics. 1952; 66 (4): 545-556.

6. Tobin J. The interest-elasticity of transactions demand for cash. The Review of Economics and Statistics. 1956;38(3):241-247. https://doi.org/10.2307/1925776

7. Miller M.H., Orr D. A model of the demand for money by firms. The Quarterly Journal of Economics. 1966;80(3):413-435. https://doi.org/10.2307/1880728

8. John T.A. Accounting measures of corporate liquidity, leverage, and costs of financial distress. Financial Management. 1993;22(3):91-100. https:// doi.org/10.2307/3665930

9. Beltz J., Murray F. Risk and corporate holdings of highly liquid assets. Unpublished Working Paper. University of British Columbia. 1996. URL: http:// citeseerx.ist.psu.edu/viewdoc/download?doi=10.1.1.1 98.3645\&rep $=$ rep $1 \&$ type $=$ pdf

10. Opler T., Pinkowitz L., Stulz R., Williamson R. The determinants and implications of corporate cash holdings. Journal of Financial Economics. 1999;52(1):3-46. https://doi.org/10.1016/S0304405X(99)00003-3

11. Park J. Financial constraints and the cash flow sensitivities of external financing: Evidence from Korea. Research in International Business and Finance. 2019;49:241-250. https://doi.org/10.1016/j. ribaf.2019.03.007

12. Myers S.C., Majluf N.S. Corporate financing and investment decisions when firms have information that investors do not. Journal of Financial Economics. 1984;13(2):187-221. https://doi.org/10.1016/0304405X(84)90023-0

13. Shyam-Sunder L., Myers S.C. Testing static tradeoff against pecking order models of capital structure. Journal of Financial Economics. 1999;51(2):219-244. https://doi.org/10.1016/S0304-405X(98)00051-8 
14. Musnadi S., Syamni G., Nasir F., Saputra J. Investigating the cash holding factors of mining industries in Indonesia Stock Exchange. Industrial Engineering \& Management Systems. 2020;19(3):527537. https://doi.org/10.7232/iems.2020.19.3.527

15. Bates T.W., Kahle K.M., Stulz R.M. Why do US firms hold so much more cash than they used to? The Journal of Finance. 2009;64(5):1985-2021. https://doi. org/10.1111/j.1540-6261.2009.01492.x

16. Almeida H., Campello M., Weisbach M.S. The cash flow sensitivity of cash. The Journal of Finance. 2004;59(4):1777-1804. https://doi.org/10.1111/j.15406261.2004.00679.x

17. Acharya V.V., Almeida H., Campello M. Is cash negative debt? A hedging perspective on corporate financial policies. Journal of Financial Intermediation. 2007;16(4):515-554. https://doi.org/10.1016/j. jfi.2007.04.001

18. Fazzari S.M., Hubbard R.G., Petersen B. Financing constraints and corporate investment. Brookings Papers on Economic Activity. 1998;(1):141-206. https://doi.org/10.2307/2534426
19. Sarkar S., Zhang C. Investment and financing decisions with learning-curve technology. Journal of Banking \& Finance. 2020;121:105967. https://doi. org/10.1016/j.jbankfin.2020.105967

20. D’Mello R., Krishnaswami S., Larkin P.J. Determinants of corporate cash holdings: Evidence from spin-offs. Journal of Banking and Finance. 2008;32(7):1209-1220. https://doi.org/10.1016/j. jbankfin.2007.10.005

21. Upneja A., Dalbor M.C. The choice of long-term debt in the U.S. lodging industry. 2001. URL: https:// www.researchgate.net/publication/271754008_The_ Choice_of_Long-Term_Debt_in_the_Hotel_Industry

22. Tang C., Jang S. Revisit to the determinants of capital structure: A comparison between lodging firms and software firms. International Journal of Hospitality Management. 2007;26(1):175-187. https://doi. org/10.1016/j.ijhm.2005.08.002

Contribution of the authors: the authors contributed equally to this article.

The authors declare no conflicts of interests.

The article was submitted 06.09.2021; approved after reviewing 08.09.2021; accepted for publication 14.09.2021. 